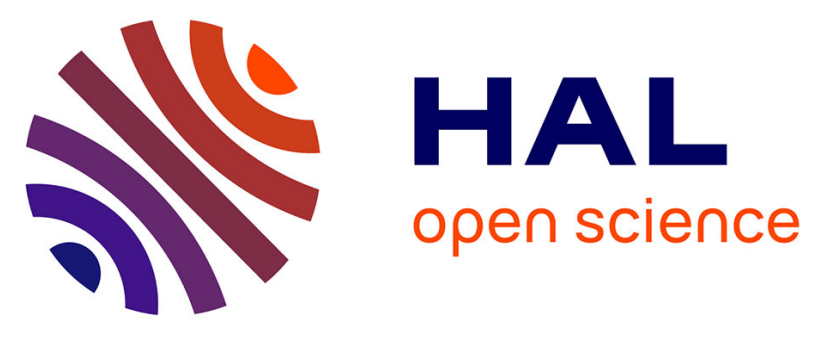

\title{
NFC Payments - Gaps Between User Perception and Reality
}

\author{
Poornigha Santhana Kumar, Michael Bechinie, Manfred Tscheligi
}

\section{To cite this version:}

Poornigha Santhana Kumar, Michael Bechinie, Manfred Tscheligi. NFC Payments - Gaps Between User Perception and Reality. Marit Hansen; Eleni Kosta; Igor Nai-Fovino; Simone Fischer-Hübner. Privacy and Identity Management. The Smart Revolution : 12th IFIP WG 9.2, 9.5, 9.6/11.7, 11.6/SIG 9.2.2 International Summer School, Ispra, Italy, September 4-8, 2017, Revised Selected Papers, AICT526, Springer International Publishing, pp.346-353, 2018, IFIP Advances in Information and Communication Technology, 978-3-319-92924-8. 10.1007/978-3-319-92925-5_23. hal-01883633

\section{HAL Id: hal-01883633 \\ https://hal.inria.fr/hal-01883633}

Submitted on 28 Sep 2018

HAL is a multi-disciplinary open access archive for the deposit and dissemination of scientific research documents, whether they are published or not. The documents may come from teaching and research institutions in France or abroad, or from public or private research centers.
L'archive ouverte pluridisciplinaire HAL, est destinée au dépôt et à la diffusion de documents scientifiques de niveau recherche, publiés ou non, émanant des établissements d'enseignement et de recherche français ou étrangers, des laboratoires publics ou privés. 


\title{
NFC payments - Gaps between user perception and reality
}

\author{
Poornigha Santhana Kumar ${ }^{1}$ Michael Bechinie ${ }^{1}$ and Manfred Tscheligi ${ }^{2}$ \\ ${ }^{1}$ USECON, 1110 Vienna, Austria \\ kumardusecon.com, bechiniedusecon.com \\ ${ }^{2}$ University of Salzburg, 5020 Salzburg, Austria \\ manfred.tscheligiesbg.ac.at
}

\begin{abstract}
Point of Sale (POS) terminals are used in almost all retail shops for commercial transactions by a wide range of users. The recent wireless payment method, Near Field Communication (NFC) is focused in this study. We aimed to study the experience gained by the user at POS terminals on privacy and security scales, while using NFC payments. The study revealed that the users have different mental models about NFC which hinders the success of the system. The results also portrays that the user experience gained from NFC payment system can be further improved. We suggest that designing/modifying the NFC payment system based on user experience will improve the privacy and security related experience gained by the user.
\end{abstract}

Keywords: NFC Payment, User Experience, Mental model.

\section{Introduction}

Near Field Communication (NFC) payment is an emerging technology and it is currently being used for contactless payments in some countries [1]. The user can easily pay by holding either their NFC card or NFC enabled mobile phone against the payment terminal. It operates at $13.56 \mathrm{MHz}$ and if the distance between the payment terminal and NFC card / NFC mobile is less than $4 \mathrm{~cm}$ a connection is established and payment is proceeded [2] [15].

We have rich literature which portrays that research is being conducted on NFC in various directions. To begin with, the advantages and possibilities of NFC technology have been well explored [2]. The main advantage pointed by various studies [2] [3] [4] states that NFC payment is faster than other payment methods (credit/debit card and cash payment) and reduce the hassles faced by the user. NFC payment also overcomes shoulder surfing attack as the user need not to input their PIN (Personal Identification Number) for purchases less than 25 euro. This transaction limit without PIN varies based on the country and the currency. The users can pay above this limit using NFC by providing their PIN. Given the above advantages, NFC payment seems to serve as a perfect alternative for existing payment methods. 
Many existing NFC literature focuses only on NFC applications [5]. There are only few research studies in the direction of usability and user experience of NFC's payment in the literature. For example: Arjan, et al. [6] studies the usability and user experience issues related to NFC payment and suggests to improve the system such that proper feedback is delivered. Another usability study [7] in the field of NFC explores the usability of NFC based interactions. The study points out the existing usability issues such as visibility and accessibility in NFC based interaction and also states that there is not enough research in this direction.

As stated by [8] "technology is deeply embedded in our ordinary everyday experience". Each service, technology or product we use in our everyday life delivers us an experience which plays an important role in accessing that particular service, technology or product. Many existing literature [8] [9] highly recommends to design based on user experience. NFC payment system also lacks research and design in this direction.

\section{Objectives}

As usability and user experience play an important role in the success of any technology and to fill the literature gap in NFC, we decided to gain deeper insights in this direction. Any user would prefer to feel secured and privacy assured at any POS. We aim to capture and enhance the experience of felt security and privacy by the user at POS. As a first step we captured the user experience of NFC payments at POS. The methodology followed and the results of this study are summarized in this paper.

\section{$3 \quad$ Methodology}

We choose to work on retail shop checkouts as they involve a wide range of customers (age, gender and profession) and accept all types of payment (cash, credit/debit card, NFC in cards and mobile phones). We used 3 methods to understand the users and the existing mental model of the users on NFC payments. The methods used and their details are as follows.

\subsection{Questionnaire}

As a first step in understanding the users, we circulated the questionnaire to a wide range of users in Austria. The questionnaire was framed in such a way that it captures the mental model of the users and their knowledge about NFC payments (Appendix A). Questions like "When do you think the NFC transaction is initiated?", "What information do you think is transferred between the card and the payment terminal during the transaction?" were asked to understand the users' existing mental model about NFC payments. Questions about the feedback of the NFC payment were asked to understand if the users perceive the intended information from the NFC payment system. Finally questions like "What do you think is the limit (in EUR) of your NFC 
payment per transaction without entering the PIN number?" and "What do you think the limit (in EUR) of your NFC payment is per day?" were asked to test the users' knowledge about NFC payments.

The questionnaire was coded in "quest back" platform and was circulated via the USECON participant database. All participants above 18 years were allowed to answer the questionnaire. The questionnaire was online from $7^{\text {th }}$ July 2017 till $30^{\text {th }}$ September 2017. At the end of 3 months we received 247 completed responses. We had $148(60 \%)$ male and $99(40 \%)$ female participants with a mean age of $38.02(\mathrm{SD}=$ 12.25). The results from the questionnaire is summarised in Table 1.

\subsection{Observation and exit interviews}

The observations and exit interviews took place in 6 supermarkets located in 6 different districts in Vienna, Austria. The districts were selected based on average net earnings of the people living in those districts to avoid biases on their shopping behaviour. Given 100 to the standard average net income, districts with $+/-10$ average net income was chosen for the study [14]. The study was conducted in the districts 2 - Leopoldstadt, 6 - Mariahilf, 9 - Alsergrund, 11 - Simmering, 14 - Penzing and 21 Floridsdorf. In each supermarket, all customers were observed for 3 hours and were asked for their willingness to give us a short exit interview. A 5 minute interview was conducted with customers who were willing. The customers were questioned on their preferred mode of payment, feedback provided by the NFC payment system, the locations they use NFC payment and the information provided by their bank on NFC payments. The customers were also asked to rate the security of the NFC payment system on a scale of 1-7 (Likert scale), 1 being less secured and 7 being highly secured.

We received a total of 179 exit interviews from 6 supermarkets. We had 78 (44\%) male and $101(56 \%)$ female customers with the mean age of $41.69(\mathrm{SD}=15.61)$. We also observed a total of 781 customers at the supermarket checkouts out of which 160 customers paid with card NFC. The customers were observed on the payment method used and customers who used NFC payment were observed for their behaviour. The NFC users were observed on how they scan their card against the payment terminal, if they receive the feedback delivered by the payment terminal and if they are aware of the situation where they have to input their PIN. The results from exit interviews are summarised in Table 2. 


\section{$4 \quad$ Results and Discussion}

\begin{tabular}{|l|l|}
\hline Description & No. of participants \\
\hline Aware of per transaction limit & $68(71 \%)$ \\
\hline Aware of per day limit & $12(12.5 \%)$ \\
\hline Participants who use mobile NFC & $13(13.5 \%)$ \\
\hline $\begin{array}{l}\text { Participants who think NFC payment } \\
\text { is less secured than credit card pay- } \\
\text { ment }\end{array}$ & $28(29 \%)$ \\
\hline $\begin{array}{l}\text { Participants who think NFC payment } \\
\text { is less secured than debit card pay- } \\
\text { ment }\end{array}$ & $30(31 \%)$ \\
\hline
\end{tabular}

Table 1. Results from the questionnaire considering only the participants ( $n=96$ out of 247) who have experience with NFC payment.

\begin{tabular}{|l|l|}
\hline Description & No. of participants \\
\hline $\begin{array}{l}\text { Not aware of information provided } \\
\text { by the bank }\end{array}$ & $94(52.5 \%)$ \\
\hline $\begin{array}{l}\text { Customers who feel NFC payment to } \\
\text { be unsecured }\end{array}$ & $65(36 \%)$ \\
\hline $\begin{array}{l}\text { Participants who perceived the visual } \\
\text { feedback from the payment terminal }\end{array}$ & $24(13 \%)$ \\
\hline $\begin{array}{l}\text { Participants who perceived the audio } \\
\text { feedback }\end{array}$ & $43(24 \%)$ \\
\hline
\end{tabular}

Table 2. Results from exit interviews in 6 supermarkets $(\mathrm{N}=179)$

\subsection{Mental Model}

The questionnaire data portrayed 85 (34\%) participants out of 247 did not have an idea about NFC. Some users also assumed NFC to be a very different technology. For example when question "what is NFC payment" users responded:

“As PayPal or similar?”

"Internet banking"

"Direct payment by means of 'moment' (identification via the iris) or "linguistic expression" (voice recognition) or personal handwriting (recognition similar to Fingerprint) ... etc." 
"A finance centre or similar to PayPal?"

The interview and observation data also portrayed that users have a different mental model regarding "How NFC payment works". The mental model among the users doesn't match with the actual working model of NFC. The below responses from participants portray the gap between the mental model(s). When sharing their thoughts about NFC payment, customers mentioned:

"Can read data of card from distance"

"Shops could take more money than they show in the terminal"

"Technology without PIN? A PIN makes sure that money comes from me"

When questioned "why the user hasn't used NFC payment" in the questionnaire, the users responded:

“Technological concerns regarding safety"

"Is too uncertain for me, this can be very easily abused"

"Lack of security"

"Security aspect - after 40 years of computer experience"

"Data is too risky for me"

The above responses show us that the users have some misassumptions about the security of NFC payments. Also, when questioned about the security of NFC systems in our questionnaires, users mentioned that they do not feel secured while using NFC payments. $30(31 \%)$ and $28(29 \%)$ users mentioned that they feel less secured while paying with NFC compared to debit and credit cards respectively. Our interview data also supports that users do not feel secured while using NFC payments. 65 customers rated the security of NFC system under 4 on a Likert scale.

These assumptions may be due to the lack of knowledge about the security and the functional model of the system. We also observed that the banks fail to provide all necessary information to the user on "what NFC is about" and "how the NFC service works". The lack of information leads to above hesitations and misassumptions.

\subsection{Lack of Information}

Similar to the functional model of the system, details about the system were also not clear among the users. Some users were not aware about the transaction limit (with 
and without PIN) and the daily limit of NFC payments. During observation, we observed that the customers were unsure of when and when not to enter their PIN. Especially when the amount to be paid is 20 to 30 EUR the users were not sure if the terminal will ask them for the PIN. 12 customers had doubts about PIN at the terminal and out of which 10 customers the bill amount was between 20 to 30 EUR.

The participants who use NFC payment were also asked to input their per transaction limit without PIN number and per day limit in the questionnaire. The participants were aware of per transaction limit compared to per day limit of their NFCs. 68 participants answered the per-transaction limit correctly whereas only $12(12.5 \%)$ of them stated their per day limit correctly.

As mentioned above, the banks do not provide transparent information about the usage of NFC on their websites. To further confirm the lack of information from banks, in exit interviews the customers were questioned if they received any information about NFC payments from their respective bank. Out of 179 customers 94 $(52.5 \%)$ customers mentioned that their banks do not provide any information on NFC payment.

\subsection{NFC cards Vs NFC mobile}

In our 6 day observation in supermarkets we did not have a single customer who paid with NFC enabled mobile phones. All the customers who used NFC used only their bank cards. When questioned about their preference in interviews, participants mentioned that they prefer cards over mobile. They also mentioned that they feel more secured with cards than with mobile.

Our questionnaire results also portray that only 13 out of 96 participants (13.5\%) of the users uses mobile NFC.

This may be due to the fact that we are used to using cards such as credit and debit cards. As they are in use for a long period now, whereas mobile payment is a recent technology. As NFC improves in terms of technology and user experience the uptake will change over time and customers will adapt to mobile NFC's similar to other technologies.

\section{$5 \quad$ Limitations}

All the parts of the user study (questionnaires, observations and interviews) were conducted in Vienna, Austria. As it is evident from literature, NFC usage and acceptance differs greatly between various countries. For example the studies [10] and [11] conducted in Korea and Malaysia respectively, predict and present different results as they were conducted in different countries. Given this, our results are geographically limited. To overcome this limitation we have planned to collect data through questionnaires from other countries and compare those results with the above obtained results. 


\section{Conclusion and Next Steps}

To conclude, our study to capture user experience of NFC payment portrays that there are several misassumptions among the users. It is also evident that the users feel unsecure to use NFC payment due to lack of consistent information and different mental models on its functional model. We believe that there is still room for improvement in NFC on usability and user experience scales and further research is required in this direction.

We will be following the Human Centred Design process [12] to investigate the problem and to design and iterate different solutions. As a next step we aim to understand users in different location and develop (or modify) a new interaction design to provide users with privacy and secured enhanced experience. With the above stated interaction design being developed and evaluated with potential users, we will be able to bring new insight and possible recommendations for improving NFC commercial transactions.

\section{$7 \quad$ Acknowledgement}

The project leading to these first results has received funding from the European Union's Horizon 2020 research and innovation program under the Marie SklodowskaCurie grant agreement No 675730. We would also like to show our gratitude to Elisabeth Ettinger (USECON) for extending her support in conducting exit interviews.

\section{References}

1. Leong, Lai-Ying, et al. "Predicting the determinants of the NFC-enabled mobile credit card acceptance: A neural networks approach." Expert Systems with Applications 40.14 (2013): 5604-5620.

2. Ok, Kerem, et al. "Current benefits and future directions of NFC services." Education and Management Technology (ICEMT), 2010 International Conference on. IEEE, 2010.

3. Pasquet, Marc, Joan Reynaud, and Christophe Rosenberger. "Secure payment with NFC mobile phone in the SmartTouch project." Collaborative Technologies and Systems, 2008. CTS 2008. International Symposium on. IEEE, 2008.

4. Massoth, Michael, and Thomas Bingel. "Performance of different mobile payment service concepts compared with a NFC-based solution." Internet and Web Applications and Services, 2009. ICIW'09. Fourth International Conference on. IEEE, 2009.

5. Coskun, Vedat, Busra Ozdenizci, and Kerem Ok. "A survey on near field communication (NFC) technology." Wireless personal communications 71.3 (2013): 2259-2294.

6. Geven, Arjan, et al. "Experiencing real-world interaction: results from a NFC user experience field trial." Proceedings of the 9th international conference on Human computer interaction with mobile devices and services. ACM, 2007.

7. Tomitsch, Martin, Thomas Grechenig, and Richard Schlögl. "Real-world tagging in the wild: On the usability and accessibility of NFC-based interactions." Workshop on Future Mobile Experiences: Next Generation Mobile Interaction and Contextualization, CoLocated with the Nordic Conference on Human-Computer Interaction, NordiCHI. 2008. 
8. McCarthy, John, and Peter Wright. "Technology as experience." interactions 11.5 (2004): 42-43.

9. Garrett, Jesse James. Elements of user experience, the: user-centered design for the web and beyond. Pearson Education, 2010.

10. Shin, Seungjae, and Won-jun Lee. "The effects of technology readiness and technology acceptance on NFC mobile payment services in Korea." Journal of Applied Business Research 30.6 (2014): 1615.

11. Tan, Garry Wei-Han, et al. "NFC mobile credit card: the next frontier of mobile payment?." Telematics and Informatics 31.2 (2014): 292-307.

12. International Organization for Standardization (2010). Ergonomics of human system interaction - Part 210: Human-centered design for interactive systems. ISO 9241-210:2010

13. International Organization for Standardization (2010). Ergonomics of human system interaction - Part 210: Human-centered design for interactive systems. ISO 9241-210:2010

14. Lohnsteuerpflichtige Einkommen nach Bezirken 2014 Frauen und Männer. (n.d.). Retrieved November 15, 2017, from https://www.wien.gv.at/statistik/arbeitsmarkt/tabellen/einkommen-gesamtbez.html

15. NFC Forum. (2017). Home - NFC Forum. [online] Available at: http://www.nfc-forum.org [Accessed 15 Nov. 2017]. 
Appendix A

1. How often do you use the following payment methods?

\begin{tabular}{|l|l|l|l|l|l|l|l|}
\hline & $\begin{array}{l}\text { Daily } \\
\text { once }\end{array}$ & $\begin{array}{l}\text { Several } \\
\text { times a } \\
\text { day }\end{array}$ & $\begin{array}{l}\text { Weekly } \\
\text { once }\end{array}$ & $\begin{array}{l}\text { Several } \\
\text { times a } \\
\text { week }\end{array}$ & $\begin{array}{l}\text { Monthly } \\
\text { once }\end{array}$ & $\begin{array}{l}\text { Several } \\
\text { times a } \\
\text { month }\end{array}$ & Never \\
\hline $\begin{array}{l}\text { Cash } \\
\text { pay- } \\
\text { ment }\end{array}$ & & & & & & \\
\hline $\begin{array}{l}\text { Debit } \\
\text { card }\end{array}$ & & & & & & \\
\hline $\begin{array}{l}\text { Credit } \\
\text { card }\end{array}$ & & & & & & \\
\hline $\begin{array}{l}\text { NFC } \\
\text { Pay- } \\
\text { ment }\end{array}$ & & & & & & \\
\hline $\begin{array}{l}\text { 2. Do you know about NFC payment? } \\
\bullet \quad \text { Yes }\end{array}$ & & & & & \\
\hline
\end{tabular}

3. Have you paid using NFC payment in any retail shop?

- Yes

- No

4. What type of NFC do you use?

- Cards

- Mobile

- Sticker

5. What do you think is the limit (in EUR) of your NFC payment per transaction without entering the PIN number?

6. What do you think is the limit (in EUR) of your NFC payment per day?

7. Does your bank provide any mobile app for managing your NFC payments? 
- Yes (if yes, please enter the app name)

- No

- I don't know

8. Do you use any third party app for managing your NFC payments?

- Yes (if yes, please enter the app name)

- $\mathrm{No}$

9. How secured is the following payments methods compared to NFC payment?

\begin{tabular}{|l|l|l|l|}
\hline & $\begin{array}{l}\text { Less secured } \\
\text { than NFC }\end{array}$ & $\begin{array}{l}\text { Equally secured as } \\
\text { NFC }\end{array}$ & $\begin{array}{l}\text { Highly secured than } \\
\text { NFC }\end{array}$ \\
\hline Cash payment & & & \\
\hline Credit card payment & & & \\
\hline Debit card payment & & & \\
\hline
\end{tabular}

10. When do you think the NFC transaction is initiated?

- When I bring my card near the payment terminal

- When I hold my card near the payment terminal

- When I place my card on the payment terminal

- None of the above

11. What information do you think is transferred between the card and the payment terminal during the transaction?

12. Which of the following payment terminal screen indicates you that the NFC payment is complete?

13. Which of the following sound from the payment terminal indicates you that the NFC payment is complete?

- Short beep

- Multiple short beeps

- Long beep

- Multiple long beeps 